DOI 10.18551/rjoas.2020-08.04

\title{
ANALYSIS OF POLLUTION LEVEL ON ASPHALT MIXING PLANT FACTORY ACTIVITIES IN GROGOL DISTRICT OF KEDIRI REGENCY, INDONESIA
}

\author{
Romadhon*, Student \\ Doctoral Study Program of Environmental Sciences, University of Brawijaya, \\ Indonesia
}

Fanani Z., Wicaksono A., Kurniawan A., Lecturers

University of Brawijaya, Indonesia

*E-mail: Ir.romadhon@yahoo.com

\begin{abstract}
This study aims to analyze the pollution level caused by the activity of the Asphalt Mixing Plant (AMP) factory in Grogol District, Kediri Regency. This research is the mixed of the survey and qualitative case study, the research location is in Bakalan village, Grogol District, Kediri Regency. Interview, scale, observation, and documentation were done for data collection. Structural Equation Modelling (SEM) and qualitative data analysis were employed for data analysis. The results showed a significant effect of the activity of AMP Factory on air quality. The main source of air pollutant concentration on AMP machines is in the dryer and bitumen heating tanks. The concentration of pollutants emitted from AMP machine consists of gas flow of $0.51 \mathrm{~m}^{3} / \mathrm{sec}$, total dust concentration of $9640 \mathrm{mg} / \mathrm{Nm}^{3}$, suspected particle of $220 \mathrm{mg} / \mathrm{Nm}^{3}$, concentrations of $\mathrm{SO}_{2}$ of $540 \mathrm{mg} / \mathrm{Nm}^{3}$, gas emission level of $15.3 \mathrm{~m}^{3} /$ tonne, dust emission level of $0.145 \mathrm{~kg} /$ tonne, estimated particle emission level of $0.0033 \mathrm{~kg} / \mathrm{tonne}$, and $\mathrm{SO}^{2}$ emission level of $0.0083 \mathrm{~kg} /$ tonne. Thus, testing the air pollutant concentration in areas within $a<200-500$ meter radius by dividing the measurement time is needed.
\end{abstract}

\section{KEY WORDS}

Pollution level, asphalt, mixing plant, factory.

On 21 October 2015, the United Nations (UN) has launched the agenda for Sustainable Development Goals (SDGs). This agenda has been established as a world agenda that contains a joint development planning frameworks up to 2030 for the sake of humans and the earth. The Indonesian government began implementing SDGs/ Sustainable Development Goals (TPB) in Indonesia by enacting the Presidential Decree No. 59 of 2017 concerning the Implementation of Sustainable Development Goals. Several challenges arise in SDGs implementation including ensuring the inclusive and no-one-left-behind principles, arranging a comprehensive, disaggregated and integrated database, and integrating the programs of government and non-government stakeholders.

One of the efforts made by the government to maintain the carrying capacity of the environment in the implementation of sustainable development goals is by implementing a green infrastructure policy. Thus, infrastructure development in Indonesia has clear directions and objectives. In addition, the desire of the nation to have a sustainable and environmentally friendly infrastructure and help reduce global warming can be realized. Government commitment to implement green infrastructure policies should prioritize the values of equality and harmony with nature. Green infrastructure is part of the economic chain and binds directly with social aspects. Every $1 \%$ development of infrastructure is able to drive economic growth by $1 \%$. Thus, campaigning for green infrastructure will also campaign for a green economy.

Related to the environment, it has been regulated in Law No. 32 of 2009 on the Environment Protection and Management (State Gazette of the Republic of Indonesia Year 2009 Number 140, Supplement to the State Gazette of the Republic of Indonesia Number 5059) which is then referred to as the PPLH. The environment as a resource is an asset that 
prospers the community. This is in accordance with Article 33 (3) of the 1945 Constitution of the Republic of Indonesia which states that the land, the waters and the natural resources within shall be under the powers of the State and shall be used to the greatest benefit of the people (Supriadi, 2005:4). Despite the law for environmental protection, the development damage environment continuously with the argument of welfare development that exploits natural resources without seriously considering the environment.

Environmental pollution and degradation in the industrial sector result from the application of exploitative modern technology without regard for the natural environment. Businesses or industries solely produce maximum material benefits. The most crucial problem faced by the industry today is environmental pollution from waste disposal from industrial activities. Waste is a by-product of the industry in the form of solids, liquids, or gases that have physical and chemical properties that can cause environmental degradation. It can be fatal to the local community if it is consumed. Therefore, the industry needs to have a good handling of industrial waste.

The management response from the Environmental Agency of East Java has carried out air quality control by increasing the Air Quality Index (AQI). The East Java Province Government has set AQI targets in 2014-2019 in the revised version of the Regional Long Term Development Plan (RPJMD). The air pollution control policy is carried out through the application of emission controls and ambient environmental quality standards through East Java's Governor Regulation No.10 year 2009. Another effort is the Implementation of East Java Governor Regulation No.67 of 2012 concerning Regional Action Plan for Reducing Greenhouse Gas Emissions which is controlled by the provincial Regional Working Unit (SKPD) with East Java Province Annual Municipal Budgets (APBD) funds.

In carrying out the development, the Kediri District is affected by poor environmental management planning. The government of the Kediri Regency overcomes the environmental problems by prioritizing environmental-related policies in the Long-Term Regional Development Plan (RPJPD) of the Kediri District in 2005-2025.

One of the industries in the Kediri Regency is an industry engaged in the construction of roads. The construction of the physical infrastructure of the road is one of the demands for the development of transportation facilities. The road encourages the growth of the road construction industry using the heavy equipment of Asphalt Mixing Plant (AMP) for the needs of road infrastructure and other industrial activities. AMP is a special production machine for making asphalt into a ready-made material for the manufacture of roads and bridges. AMP is a set of mechanical and electronic equipment for mixing aggregate with asphalt to produce ready-to-use hot asphalt mixtures with certain requirements according to specified specifications.

This study is focused on the activities of AMP machine and material transportation in and out of industrial locations. The potential of the AMP machine is predicted to cause the most air pollution compared to other machines in the integrated industrial complex in Kediri Regency, while the transportation of material in and out of the Industrial area has the potential to cause air pollution by dust since the industrial area is a dirt road. The problem formulated in this study is intended to see the level of pollution in the activity of the Asphalt Mixing Plant (AMP) in the Grogol District, Kediri Regency.

\section{METHODS OF RESEARCH}

This study uses a mixed methodology. According to Creswell (2014), a mixed-method refers to "a methodology that provides philosophical assumptions in showing direction or giving instructions on how to collect and analyze data as well as the combination of quantitative and qualitative approaches through several phases of the research process. This research uses a gradual mixture technique. This strategy can be done by interviewing to get qualitative data and then, quantitative data. In this study, it used a survey and case study.

Data collection was carried out using interviews, scale, observation, and documentation. The data were collected through direct measurements of informants of the AMP factory management in Bakalan Village, Grogol Subdistrict, Kediri Regency, local 
communities around the factory, Local Government of Kediri Regency, and Village Government.

Data analysis and interpretation methods used are SEM (Structural Equation Modeling) and Qualitative Data Analysis. SEM is a multivariate analysis that can analyze variable relationships in a complex way. SEM is able to explain the relationships between variables in the exogenous and endogenous latent variables in the study. The second analysis is a qualitative data analysis that aims to organize the data and reduce the data to a manageable unit as well as finding the level of environmental pollution from the activities of the Asphalt Mixing Plant (AMP) factory in Bakalan Village, Grogol District, Kediri Regency.

\section{RESULTS AND DISCUSSION}

AMP management system in PT triple S Putra construction is grouped into three stages of activities. First, the preparation/ pre-construction consisting of several stages: socialization and land use permit. Second, the construction phase including mobilization and demobilization of equipment and material, measurement and benchmarking, confinement, and workforce recruitment development. The Third Phase is the Operational Stage.

The operational phase of PT Triple S Putra Kediri consists of several activities:

- The procurement of raw materials construction using AMP consisting of river stones and filler material derived from mining of the material of the eruption of Mount Kelud located in Sabo Dam in Kediri and Blitar, Asphalt from agents/official distributor from Pertamina namely PT. Surya Agung Nusantara, located on Jl. Manyar Tirto Asri XII/37 Surabaya. The diesel fuel is obtained from PT. AKR Corporindo Ybk, a company holding a business license for fuel oil (BBM);

- The weighing to find out the weight of material or aggregates and fillers entering and leaving the stockpile or location;

- Storage of Raw Materials by placing and piling them in an open space. It aims to maintain the production to run smoothly and take place continuously. The aggregate or filler stones are resistant to sunlight, water, or air. Whereas asphalt is stored in a tank and diesel is put into a bunker fuel;

- The Stone Milling Process by grinding stone for the mixture of the material making the taua laston/asphalt concrete road;

- The Asphalt Mixing Plant is a set of mechanical and electronic equipment that aggregates are heated, dried, and mixed with asphalt to produce hot asphalt mixtures that meet certain requirements;

- Transportation from the location of the source of raw materials using a drump truck and a truck with a closed transportation system. The transportation of hot mix asphalt to the location of road construction also uses a dump truck.

The results of the study show that the conversion of the path diagram into the measurement model can be identified through an explanation of the AMP factory activity variable measurement model. Based on the measurement model, it is revealed that the loading value of the indicator of AMP operational activity (X1.1) is 0.800 . This means that the variance of the variable of AMP factory activity $(\mathrm{X} 1)$ can be explained by the AMP operational activity (X1.1) by $80.0 \%$. In other words, the contribution of the indicator of AMP operational activity (X1.1) in measuring the variable of AMP factory activity (X1) is $80.0 \%$. The loading value of the indicator of waste disposal $(\mathrm{X} 1.2)$ is 0.850 . This means that the variance of the variable of AMP factory activity (X1) can be explained by the indicator of waste disposal $(\mathrm{X} 1.2)$ by $85.0 \%$. In other words, the indicator of waste disposal (X1.2) in measuring the variable of AMP factory activity (X1) is $85.0 \%$.

The loading value of the indicator of the AMP waste treatment plant $(X 1.3)$ is 0.633 . This shows that the variance of the variable of the AMP factory activity (X1) can be explained by the indicator of the AMP waste treatment plant $(\mathrm{X} 1.3)$ by $63.3 \%$. In other words, the contribution of the indicator of the AMP waste treatment plant (X1.3) in measuring the variable of the AMP factory activity $(X 1)$ is $63.3 \%$. Next, the loading value of the indicator of internal waste management $(\mathrm{X} 1.4)$ is 0.614 . This means that the variance of the variable of 
AMP factory activity (X1) can be explained by the indicator of internal waste management (X1.4)by $61.4 \%$. In other words, the contribution of the indicator of internal waste management (X1.4) in measuring the variable of AMP factory activity (X1) is $61.4 \%$. the variable of AMP factory activity (X1) measurement model reports that the indicator of waste disposal (X1.2) has the highest loading value. This means that the indicator of waste disposal $(X 1.2)$ is the most dominant indicator in measuring the variable of AMP factory activity $(\mathrm{X} 1)$.

The Hypothesis testing relates to the effect of AMP factory activities on air quality. The test result shows that the t-statistic of the relationship between AMP factory activities and air quality is 2.382 . The test results show that the value of t-statistics $>1.96$. This means that there is a significant effect of AMP factory activity on air quality. Thus the hypothesis is accepted.

The conversion of the path diagram in the measurement model is to determine the direct and indirect effect. The effect of the direct and indirect model in the structural model formed is the equation 1: $\mathrm{Y} 1=-0,098 \times 1$, that the coefficient of the direct effect of AMP factory activity on air quality is -0.098 . It shows that AMP factory activity has a negative and significant effect on quality air. This means that the higher the AMP factory activity, the more the decrease in air quality. Equation 2: $\mathrm{Y} 2=0.044 \mathrm{X} 1$ shows that the coefficient of the direct effect of AMP factory activity on the model of air pollution prevention strategy due to AMP machine activity is 0.044 . AMP factory activity has a positive and not significant effect on the model of air pollution prevention strategy due to AMP machine activity. This means that the higher the AMP factory activity, the more improved the air pollution prevention strategy due to AMP machine. However, the improvement is not significant.

Harssema in Mulia (2005) explains that air pollution starts with emissions. Emissions are the number of pollutants released into the air in the unit of time. Emissions are caused by nature or human. The natural processes are called biogenic emission, for example, Methane $\left(\mathrm{CH}_{4}\right)$ as a result of decomposition of organic material by decomposing bacteria. Air emissions caused by human activities are the result of burnt fossil fuels (gasoline, diesel, coal) and the use of chemicals that are sprayed into the air and so on. According to Sarudji (2010), some of the most common types of air pollutants are sulfur dioxide $\left(\mathrm{SO}_{2}\right)$, carbon monoxide $(\mathrm{CO})$, nitrogen oxide $\left(\mathrm{NO}_{\mathrm{x}}\right)$, and dust (particulate matter).

The main source of air pollutant concentrations on AMP machines is in the dryer and bitumen heating tank. In order to get the right heating effect on the aggregate in the dryer, the draft is created by providing an induced draft fan (ID). This causes a lot of fine dust to enter the aggregate. An experiment carried out by the Asphalt Institute (USA) on dust emissions from dryers are presented in the following table 1 (Prathima, et al., 2017:19416):

Table 1 - The concentration of Dust Emissions from Dryer Asphalt Mixing Plant (AMP)

\begin{tabular}{|c|c|c|c|}
\hline No. & Item & Unit & Value \\
\hline 1 & Gas flow & $\mathrm{m} 3 / \mathrm{sec}$ & 0.51 \\
\hline 2 & Total dust concentrations & $\mathrm{mg} / \mathrm{N} \mathrm{m3}$ & 9640 \\
\hline 3 & Suspected particle & $\mathrm{mg} / \mathrm{N} \mathrm{m3}$ & 220 \\
\hline 4 & $\mathrm{SO}_{2}$ concentration & $\mathrm{mg} / \mathrm{N} \mathrm{m} 3$ & 540 \\
\hline 5 & Gas emission level & m3/tonne & 15.3 \\
\hline 6 & Dust emission level & $\mathrm{kg} /$ tonne & 0.145 \\
\hline 7 & Suspected level of particle emission & $\mathrm{kg} /$ tonne & 0.0033 \\
\hline 8 & $\mathrm{SO}_{2}$ emission level & $\mathrm{kg} /$ tonne & 0.0083 \\
\hline
\end{tabular}

The main source of pollutant concentrations in bitumen heating tanks is when it is heated, the bitumen as liquid state releases heat from volatile organic gas in the form of blue smoke emissions. This is thrown through the chimney into the atmosphere. The pollutants released when the bitumen is heated into liquid can be seen in Table 2 (Prathima, et al., 2017:19416).

The main source of air pollutant concentration on the machine is in the dryer and bitumen heating tanks. Dryer as a concentration of dust emissions makes the level of pollutants can be seen from the activity of the AMP machine. This dryer determines the pollutants that affect the level of pollutants released by bitumen heating tanks when it is 
heated. The results of this study show that the variable of AMP factory activity measurement model with the indicator of residual waste has the greatest loading value. Thus, the indicator of residual waste is the most dominant indicator in measuring the variable of AMP factory activity. Thus, the AMP factory activity has a negative and significant effect on air quality. This means that the higher the AMP factory activity, the more the decrease of air quality.

Table 2 - Pollutants Released during Bitumen Heating to become Liquid

\begin{tabular}{|c|c|c|c|}
\hline No. & Item & Unit & Concentration (Value) \\
\hline 1 & Carbon monoxide & $\mathrm{ppm}$ & 6.00000 \\
\hline 2 & Nitrogen Dioxide & ppm & 0.10000 \\
\hline 3 & Sulfur dioxide & ppm & 2.00000 \\
\hline 4 & Hydrogen sulfate & $\mathrm{ppm}$ & 1,50000 \\
\hline 5 & Phenol & ppm & 1.00000 \\
\hline 6 & Ozone & $\mathrm{ppm}$ & 0.10000 \\
\hline 7 & Hydrocarbons (C1 -C14) & ppm & 1,50000 \\
\hline 8 & Hydrocarbons (C2 -C6) & ppm & 1.00000 \\
\hline 9 & Particulate material & $\mathrm{mg} / \mathrm{m} 3$ & 7,20000 \\
\hline 10 & Computational Polynuclear Aromatic (total) $\mathrm{mg} / \mathrm{m}^{3}$ & $\mathrm{mg} / \mathrm{m} 3$ & 0.00036 \\
\hline 11 & Vanadium, V2U5 smoke & $\mathrm{mg} / \mathrm{m} 3$ & 0.00010 \\
\hline 12 & Nickel and soluble nickel compounds (such as Ni) & $\mathrm{mg} / \mathrm{m} 3$ & 0.00004 \\
\hline 13 & Cadmium fume & $\mathrm{mg} / \mathrm{m} 3$ & 0.00005 \\
\hline 14 & Computational Lead and inorganic & $\mathrm{mg} / \mathrm{m3}$ & 0.00005 \\
\hline
\end{tabular}

The consideration in using AMP is needed due to the pollutants by taking into account environmental quality standards. According to Siahaan (1987: 163-164), if the quality standards are not met or if the amount of certain substances or energy that invades the environment exceeds the carrying capacity of the environment, the environment has been damaged or have degraded that could endanger life. Hence, the maximum limit of substances or energy that may be put into the environment media (threshold) should be set.

A study by Prathima, et al., (2017: 19416) entitled "A Case Study on Pollutants Emission and Environmental Management Plan for Hot Mix Asphalt Plant" concludes that: (1) first, toxic gases are produced during mixing of heated aggregate and bitumen and (2) the noise pollution produced is around 80 to $90 \mathrm{~dB}$, which is within the standards set by the occupational safety and health administration (OSHA), US.

In addition, Nolan (2017), in research entitled "Screening Air Modelling Assessment of Emissions from Asphalt Batching Plant in Croom Co. Limerick" concluded that the model of AERSCREEN air dispersion is used to model $\mathrm{NO}_{2}, \mathrm{CO}$, and particulates (PM10/PM2.5) in the surrounding environment. The dispersion model predicts the worst soil surface concentrations of these pollutants at distances from $20 \mathrm{~m}-5000 \mathrm{~m}$ from the source.

\section{CONCLUSION}

The conclusion drawn from this study is that the main source of the pollutant concentrations in the air pollutant is in the dryer and bitumen heating tanks. The concentration of pollutants that polluted air emitted from AMP machine consists of a gas flow of $0.51 \mathrm{~m} 3 / \mathrm{sec}$, total dust concentration of $9640 \mathrm{mg} / \mathrm{N} \mathrm{m} 3$, suspected particle of $220 \mathrm{mg} / \mathrm{N}$ $\mathrm{m} 3, \mathrm{SO}_{2}$ concentration of $540 \mathrm{mg} / \mathrm{N} \mathrm{m} 3$, gas emission level of $15.3 \mathrm{~m} 3 /$ tonne, dust emission level of $0.145 \mathrm{~kg} /$ tonne, estimated particle emission level of $0.0033 \mathrm{~kg} /$ tonne, and $\mathrm{SO}_{2}$ emission level of $0.0083 \mathrm{~kg} /$ tonne. Thus, it is necessary to test the concentration of air pollutants in areas with a radius of $<200-500 \mathrm{~m}$ with the distribution of measurement time and periodic monitoring and control by the Environmental Agency of Kediri Regency.

\section{REFERENCES}

1. Creswell, John W.,2010. Research design: pendekatan kualitatif, kuantitatif, and mixed. Yogjakarta: PT Pustaka Pelajar.

2. Dokumen Informasi Kinerja Pengelolaan Lingkungan Hidup Daerah Provinsi Jawa Timur (Provinsi Jawa Timur, 2018:III-17). 
3. Mulia, Ricki M., 2005. Kesehatan Lingkungan. Yogyakarta: Graha Ilmu.

4. Nolan, Ciara. 2017. "Screening Air Modelling Assessment Of Emissions From Asphalt Batching Plant In Croom Co. Limerick". Technical Report Prepared For McCarthy Keville O'Sullivan Ltd. Planning \& Environmental Consultants Block 1, G.F.S.C. Moneenageisha Road, Galway. Awn consulting.

5. Peraturan Gubernur Jawa Timur Nomor 10 Tahun 2009 tentang Baku Mutu Udara Ambien and Emisi Sumber Tidak Bergerak di Jawa Timur.

6. Prathima, Krishnareddygari and B.Kotaiah. 2017. "A Case Study on Pollutants Emission and Environmental Management Plan for Hot Mix Asphalt Plant". Dalam International Journal of Innovative Research in Science, Engineering and Technology (A High Impact Factor \& UGC Approved Journal), DOI:10.15680/IJIRSET.2017.0609114, ISSN(Online): 23198753, ISSN (Print): 2347-671.

7. Sarudji, D, 2010. Kesehatan Lingkungan. Bandung: CV. Karya Putra Darwati.

8. Siahaan, N.H.T., 1987. Ekologi Pembangunan and Hukum Tata Lingkungan. Jakarta: Erlangga.

9. Supriadi, 2006. Hukum Lingkungan di Indonesia. Jakarta: Sinar Grafika.

10. Undang-Undang Nomor 32 Tahun 2009 Tentang Perlindungan and Pengelolaan Lingkungan Hidup. 